УДК 902/904

ББК $63.4(2)$

DOI $10.31554 / 2222-9175-2019-34-267-271$

Б. А. Базаров

АВА ГОАА АРХЕОАОГИЧЕСКИХ ЭКСПЕАИЦИЙ

И МЕЖАУНАРОАНОЕ СОТРУАНИЧЕСТВО В РАМКАХ РЕААИЗАЦИИ МЕГАГРАНТА «АИНАМИКА НАРОАОВ И ИМПЕРИИ В ИСТОРИИ ВНУТРЕННЕЙ АЗИИ»

\author{
B. A. Bazarov
}

\title{
TWO YEARS OF ARCHAEOLOGICAL EXPEDITIONS AND INTERNATIONAL COOPERATION IN THE FRAMEWORK OF MEGAGRANT "DYNAMICS OF PEOPLES AND EMPIRES IN INNER ASIA"
}

$\mathrm{B}_{\mathrm{r}}^{201}$ 2017 г. в рамках реализации научно-исследовательского проекта (мегагранта) «Динамика народов и империй в истории Внутренней Азии» была создана лаборатория археологии, этнологии и антропологии Института монголоведения, буддологии и тибетологии СО РАН. Научным руководителем ее стал ведущий российский ученый с мировым именем, член-корреспондент РАН, доктор ист. наук, профессор Николай Николаевич Крадин. Лаборатория является междисциплинарным научным центром для комплексного исследования структурной динамики исторического развития народов Внутренней Азии в пространственно-временных связях межцивилизационного и межкультурного взаимодействия. Над реализацией масштабного проекта трудится многочисленный коллектив из более трех десятков специалистов в области истории, археологии, антропологии, этнологии, филологии, философии, религиоведения, естественных наук.

Особое внимание в деятельности института уделяется международному сотрудничеству. Приняты соглашения с научными и образовательными учреждениями Монголии, Германии, Франции, Японии, Республики Корея. Совместные исследования с французскими учеными в области генетики имеют громадное значение в изучении происхождения и миграции народов и эволюции их культур. В сотрудничестве с коллегами из Германии реконструированы палеоклиматические флуктуации и охарактеризован начальный этап неолита. За последнее десятилетие отмечено значительное расширение географии международных связей института с зарубежными научными учреждениями, а с созданием лаборатории международные контакты получают новый импульс, и немаловажную роль в этом играет ее научный руководитель. Происходит интенсификация археологических экспедиционных исследований на территории как Республики Бурятия и сопредельных регионов, так и Монголии.

1. Поселение Муханские озера IV. Руководитель Н. В. Цыденова. Археологические раскопки проводились в долине р. Кодун на поселении Муханские озера IV в Кижингинском районе Республики Бурятия. Материалы этой стоянки относятся к

БАЗАРОВ Биликто Александрович - сотрудник лаборатории археологии, этнологии и антропологии Федерального государственного бюджетного учреждения науки «Институт монголоведения, буддологии и тибетологии СО РАН» (Улан-Удэ, Россия). E-mail: biliktobazarov@yandex.ru. 
периодам раннего (1 к.г.) и развитого бронзового века (2 к.г.). Все материалы фиксируются в строгой стратиграфической последовательности. Остеологическая коллекция представлена костями диких и домашних животных. Стоянка «Муханские озера IV» является одним из немногих стратифицированных объектов, содержащим костные остатки домашних животных (лошадь и овца), и свидетельствует о появлении первых скотоводов в Забайкалье. На материалах данной стоянки решается проблема возникновения производящего хозяйства на территории западного Забайкалья.

2. Многослойное местонахождение «Три скальл». Руководитель к.и.н. В. И. Ташак. В ходе стационарных раскопочных работ на многослойном местонахождении «Три скалы» (Тарбагатайский район Республики Бурятия) исследованию подверглись верхние культурные горизонты, датируемые в диапазоне от бронзового века до Средневековья. Раскопана серия кострищ без обкладок и выраженных сопровождающих конструкций на поверхности литологического слоя 2. Малое количество костей позволяет сделать вывод, что здесь функционировали кратковременные стоянки, связанные только с ритуальной деятельностью (например, организация тризн), поскольку в непосредственной близости зафиксированы погребально-ритуальные комплексы, представленные курганами-керексурами, плиточными могилами, захоронениями хунну, средневековыми погребениями и петроглифами. В дополнение к стационарным проведены рекогносцировочные работы в Окинском районе Республики Бурятия с целью определения перспективных направлений археологического изучения территории. В ходе археологической разведки были выявлены объекты с инситными культурными горизонтами новокаменного и бронзового веков.

3. Археолого-геологическая разведка в Хоринском, Кижингинском и Бичурском районах Республики Бурятия. Руководитель к.и.н. А. И. Симухин. Цель - обследование территорий согласно данным геологии и письменным источникам о древних рудных выработках. В разведке принимали участие специалисты Геологического института СО РАН д.г.-м.н. Б. Б. Дамдинов и к.г.-м.н. В. Б. Хубанов. Найдено несколько месторождений и рудных выработок, которые могут иметь отношение к древней металлургии меди и железа в Западном Забайкалье. Отобраны образцы руд для исследований и корреляций с данными элементного состава археологических коллекций из металла. Попутно были обследованы известные и выявлены археологические объекты бронзового - раннего железного веков на территории западного Забайкалья.

4. Археологические раскопки на Иволгинском городище. Руководитель чл.-кор. РАН, д.и.н. Н. Н. Крадин. Перед началом археологических работ на площади оседлого памятника хуннской археологической культуры были проведены геофизические работы, которые позволили выделить элементы пространственной планировки западной части городища. За два года раскопок на Иволгинском городище обнаружены остатки трех жилищ полуземляночного типа и многочисленные хозяйственные ямы, давшие разнообразный материал для реконструкции палеогеографических условий, хозяйственной деятельности, духовной культуры и т. д. Общая площадь вскрытой раскопами площади составила 270 кв. м. Внутри жилищ просматриваются следы отопительных систем (канов). Раскопками зафиксировано несколько строительных уровней. Помимо массового материала, представленного керамикой и костными остатками животных, особый интерес вызывает категория индивидуальных находок. Это фрагменты венчиков металлических котлов, костяная протома хищного животного, фрагмент бронзового зеркала, ложечковидная пряжка, биметаллический наконечник стрелы, костяные наконечники стрел, костяной свистунок стрелы, несколько каменных пряжек (одна с инкрустацией перламутром), имитации 
раковин каури, костяные, каменные и стеклянные бусины, костяное орудие для орнаментации керамических сосудов и керамические игральные фишки. На этом уникальном памятнике апробируется весьма широкий спектр методического арсенала естественных наук.

В раскопках Иволгинского городища активное участие принимает Джин-Сон Хан, научный сотрудник Института корейской археологии и древней истории Университета Кьюн Хе (Республика Корея).

5. Российско-монгольская экспедиция по изучению средневекового памятника «Городище Хэрмэн-дэнж». Руководитель чл.-кор. РАН, д.и.н. Н. Н. Крадин. Городище Хэрмэн-дэнж (империя Ляо) расположено в Заамар сомоне Центрального аймака Монголии. Обследованию подверглось крупное здание с глинобитными стенами. После расчистки на всей площади раскопа обнажился развал черепицы и кирпича от кровли здания. Ниже этого слоя зафиксирован плотный глиняный пол. Остатки стен достигают в высоту около 1 м. Под стеной в северо-восточном углу здания найдена квадратная каменная база, лицевая поверхность которой покрыта параллельными косыми бороздками. Еще одна квадратная каменная база найдена внутри здания. Кровля крыши состояла из плоских и желобчатых черепиц. Концевые диски, украшенные стилизованными изображениями цветка лотоса, найдены на краях платформы или возле нее, снаружи от стен здания. Кроме того были обнаружены костные останки домашних животных, мелкие металлические изделия и фрагменты гончарных изделий. Таким образом, в ходе археологических раскопок были получены новые данные о применяемых строительных материалах на городище и установлены конструктивные особенности изучаемого жилища.

6. Неукрепленное поселение хунну «Нижний Мангиртуй». Руководитель к.и.н. Д. А. Миягашев. Памятник археологии расположен в Бичурском районе Республики Бурятия. Здесь также перед началом археологических раскопок были проведены геофизические исследования, показавшие сложную застройку площади поселения. В силу этого исследования были сосредоточены на корреляции данных, полученных методами георадиолокационных исследований. Раскоп был заложен на участке, где по геофизическим данным имелось наличие четких следов погребенных конструкций прямоугольной формы. В ходе раскопок было исследовано жилище полуземляночного типа и несколько хозяйственных ям. Котлован жилища имел подпрямоугольную форму. Вход в жилище располагался с южной стороны. Отопительная система была демонтирована, на месте топки (северо-восточный угол) сохранились отдельные каменные плиты. Материалы поселения будут датированы AMS-методом в Боннском университете в Германии, пробы грунта отданы на фосфатный анализ в Тихоокеанский океанологический институт ДВО РАН, изучение карпоидов проводится в Институте истории, археологии и этнографии ДВО РАН, анализ стабильных изотопов проведен в Геологическом институте СО РАН.

В экспедиции по изучению Нижне-Мангиртуйского поселения в 2017 г. работала Джин-Сон Хан, научный сотрудник Института корейской археологии и древней истории Университета Кьюн Хе (Республика Корея).

7. Хуннский могильник Нур-Тухум. Руководитель Б. А. Базаров. Археологические раскопки сосредоточены в двух пунктах нового могильника, расположенного в Селенгинском районе Республики Бурятия: в пункте I изучено 3 хуннских погребения, в пункте 2 раскопано два хуннских погребения с ритуальной кладкой и одно средневековое погребение. Общее количество погребений в могильнике - 110, что делает его одним из крупных могильников хунну на территории Западного Забайкалья. На площади могильника проведены геофизические исследования, демонстрирующие различные параметры погребальных конструкций и наличие различных аномалий 
антропогенного и природного характера. Надмогильные конструкции фиксируются в виде кольцевидных каменных выкладок на современной дневной поверхности. Внутримогильные конструкции без вариаций, представлены только срубом, который, как правило, обложен по периметру каменными плитами и валунами. Верхнее перекрытие могил не сохранилось. Хуннские погребения ориентированы по линии север - юг. Все могилы разграблены. В срубах обнаружены немногочисленные кости человека, а также кости животных в хозяйственном отсеке. Сопроводительный инвентарь представлен фрагментами керамических сосудов, осколком бронзового китайского зеркала (см. статью в настоящем номере), бронзовой пуговицей, костяными накладками на лук, роговой псалией. В средневековом захоронении костяк сохранился в анатомическом порядке. Погребение ориентировано по линии запад - восток. В качестве сопроводительного инвентаря в могилу были положены украшения из четырех каменных бусин и железный нож. Материалы этого могильника использованы для проведения анализа стабильных изотопов в целях реконструкции ландшафтно-климатических условий и диеты, радиоуглеродного датирования и палеогенетических исследований.

8. Археологические работы в пади Липовка. Руководитель Б. А. Базаров. Детское хуннское кладбище в пади Липовка расположено на небольшом расстоянии к западу от могильника Ильмовая падь (Кяхтинский район Республики Бурятия). На этом объекте зафиксирована серия детских ингумаций в глиняных сосудах. Традиция захоронения детей в глиняных сосудах впервые была зафиксирована во время раскопок Иволгинского городища. На сегодняшний момент в пади Липовка имеется целая серия находок детских захоронений в глиняных сосудах. Продолжение исследований на этом уникальном объекте позволит определить интрамуральность детских погребений, а также реконструировать тип питания хуннских детей на основе анализа стабильных изотопов, проводимого в институте Макса Планка (Алисия В. Миллер).

9. Российско-монгольская этноархеологическая экспедищия «Древние и средневековые города и поселения». В рамках мегагранта продолжаются работы над созданием «Атласа древних и средневековых городов и поселений Центральной Азии и Южной Сибири». С монгольской стороны в работе участвуют Институт кочевых цивилизаций, Монгольский государственный университет науки и технологий и Институт истории и археологии Академии наук Монголии. Полевые работы осуществлялись на территории Республики Бурятия, Монголии и Иркутской области. Выявлялись памятники археологии, определялась степень сохранности всех объектов, производилась съемка городищ и поселений БПЛА Phantom-3. На территории Республики Бурятия съемками были охвачены все известные поселения эпохи хунну и средневековья. В Монголии археологические разведки проведены в восточных, центральных и северо-западных аймаках страны. На территории Иркутской области выявлены поселения с фортификационными сооружениями, расположенные высоко над долинами рек, на горных плато. Второй тип памятников концентрируется большей частью по побережью Байкала и имеет сакральный характер. Все материалы в последующем анализируются геоинформационными системами.

В заключение отметим, что в рамках реализации мегагранта нашими исследованиями широко охвачен круг вопросов, связанных с фундаментальными темами изучения становления производящих форм хозяйства, культурогенеза и социогенеза у древнего населения Внутренней Азии. В соответствии с задачами и планом реализации проекта проводятся масштабные научно-исследовательские, научно-организационные и экспедиционные работы. Было положено начало формированию уникальной источниковой базы исследований динамики исторических процессов 
Внутренней Азии. Значительный объем работ проделан по изучению опорных и известных археологических памятников и выявлению объектов археологического наследия на территории Бурятии и Монголии.

Важной составляющей проекта, безусловно, является блок аналитических работ по изучению археологического материала. На основе данных, полученных в результате проведения естественнонаучных анализов, сформированы новые представления, которые конкретизируют реконструкции условий окружающей среды и климата, систем жизнеобеспечения, являющихся важными моментами, определяющими динамику материальной культуры и общественных процессов. Краеугольным камнем проекта являются палеогенетические исследования, материал для которых получен, систематизирован и отобран в ходе выполнения экспедиционных и камеральных археологических работ.

Работа выполнена при поддержке гранта Правительства Российской Федераџии № 14.W03.31.0016 «Динамика народов и империй в истории Внутренней Азии». 